\title{
Cash-for-Passports and the End of Citizenship
}

\author{
Peter J. Spiro
}

Investor citizenship programmes are becoming increasingly commonplace in state practice. What was once the province of outlier Caribbean microstates is gaining traction among more substantial states. As an instrumental tool, states see citizenship-for-sale as a way to help get out of an economic hole on the cheap. There is no marginal material cost to minting new citizens, especially those with deep enough pockets to afford the price of admission. Hence the adoption of investor citizenship programmes by such countries as Cyprus, Malta, and Portugal.

I sympathise with Ayelet Shachar's powerful framing of these programmes. There is something unseemly, at least, about putting membership in the polity up for sale. Cash-for-passports, as Shachar derisively labels the phenomenon, clashes with our received understandings of citizenship as a marker of social solidarity in a Walzerian sense. The emerging market for citizenship literally commodifies the status, the tip of an iceberg that Shachar is describing in other work as states come to see immigration as a talent-pool competition.

But where Shachar sees investor citizenship programmes as a threat to robust citizenship ties, I see them more as a manifestation of citizenship that is already being hollowed out. If citizenship still meant what it used to mean, if it still represented special ties as a sociological matter, then investor citizenship schemes would not exist. In that context, citizenship-for-sale would have implicated serious symbolic societal costs by breaking the social contract, understood not as an arm's-length market transaction but rather as the locus of morally-inflected rights and responsibilities. In the old world, such programmes would have been inconceivable.

Today, far from inconceivable, they are becoming an accepted element of strategic immigration policy. Investor citizenship programmes remain controversial (perhaps especially in a small, distinctive society such as Malta, which may more represent the old norm rather the new). But they are obviously gaining traction. States have something to sell. There must be some sentiment in adopting states that the revenues will exceed costs, social or otherwise. 
Investor programmes give the lie to notion that citizenship is sacred, in a civic sense. The programmes evidence the descent of citizenship from its former pedestal. Shachar extols a 'vision of citizenship as grounded in longterm relations of trust and shared responsibility, ... membership bonds grounded in co-authorship, cross-subsidisation of risk, and even sacrifice that might be expected in times of need.' That's the citizenship of the past, and passport-for-sale schemes supply another data point to prove it.

This is so notwithstanding externalities imposed on other states. In some contexts, these externalities will be miniscule (a citizen of Malta can travel to the United States visa free where the citizen of Russia cannot, but the numbers will be low, and the number who abuse visa-free entry will be even lower). In the European context they are potentially greater, as the EU member states become subject to lowest-common-denominator citizenship policies. Those who buy Maltese citizenship are less likely to settle in Valletta (one wonders how many could even name the capital city before - or perhaps even after - they have made the purchase) than in Berlin or Paris or Milan. When one buys Maltese citizenship one gets EU citizenship included in the price; it opens a backdoor to the rest of Europe. But the EU seems unlikely to complain. There is no legal basis for opposition, citizenship policy remaining exclusively within Member State discretion. Nor is there likely to be much pushback as a policy matter, so long as the price is high enough to depress numbers and maintain economic quality (as it were).

In material terms, the programmes are not much of a threat to provider states, either. The numbers will be low. (Portugal had only 330 takers in the first year of its program.) Because many buyers will remain non-resident, they will be invisible to the existing citizenry. They will not be politically engaged, to the extent they will feel no interest beyond protection of their bought-and-paid status. One possible cost would be with respect to diplomatic protection. It will be interesting to see whether that is a part of a bargain - whether in fact states will intercede with other states on behalf of their paying members (and whether international tribunals would recognise protection of cash-only nationals).

Shachar is correct that the investor programmes show that citizenship is still worth something. As the market thickens, we will see how much. With the reference point of states that sell permanent residency, we will be able approximately to isolate the value of citizenship itself - the premium states will be able to extract with the passport. Will investor programmes like Malta's, which offer citizenship, be priced much higher than Hungary's, which extends residency status only? (I will leave to the economists to deal with asymmetries among the various packages.) I suspect that premium will 
not be great, especially insofar as permanent residency includes the possibility of future eligibility for naturalisation. Finally, there is the possibility of price competition as more states enter the market and some seek to maximise revenues by attracting more buyers at a lower price point.

Investor citizenship programmes are a symptom, not a cause. Shachar sees citizenship as something that can be rescued through citizenship policy. As material forces of globalisation fragment citizens' solidarities, citizenship law cannot revive them.

Open Access This chapter is licensed under the terms of the Creative Commons Attribution 4.0 International License (http://creativecommons.org/licenses/by/4.0/), which permits use, sharing, adaptation, distribution and reproduction in any medium or format, as long as you give appropriate credit to the original author(s) and the source, provide a link to the Creative Commons license and indicate if changes were made.

The images or other third party material in this chapter are included in the chapter's Creative Commons license, unless indicated otherwise in a credit line to the material. If material is not included in the chapter's Creative Commons license and your intended use is not permitted by statutory regulation or exceeds the permitted use, you will need to obtain permission directly from the copyright holder.

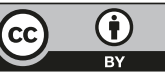

